\title{
Spinosity, regeneration, and targeting among Paleozoic crinoids and their predators
}

\author{
Valerie J. P. Syverson, Carlton E. Brett, Forest J. Gahn, and Tomasz K. Baumiller
}

\begin{abstract}
Evolving interactions between predators and prey constitute one of the major adaptive influences on marine animals during the Paleozoic. Crinoids and fish constitute a predator-prey system that may date back to at least the Silurian, as suggested by patterns of crinoid regeneration and spinosity in concert with changes in the predatory fauna. Here we present data on the frequency of breakage and regeneration in the spines of the Middle Devonian camerate Gennaeocrinus and late Paleozoic cladids, as well as an expanded survey of the prevalence of spinosity and infestation by platyceratid gastropods on crinoid genera during the Paleozoic. Spine regeneration frequency in the measured populations is comparable to arm regeneration frequencies from Mississippian Rhodocrinites and from modern deepwater crinoid populations. The prevalence of spinosity varies by taxon, time, and anatomy among Paleozoic crinoids; notably, spinosity in camerates increased from the Silurian through the Mississippian and decreased sharply during the Pennsylvanian, whereas spines were uncommon in cladids until their Late Mississippian diversification. Among camerates, tegmen spinosity is positively correlated with the presence of infesting platyceratid gastropods. These results allow us to evaluate several hypotheses for the effects of predation on morphological differences between early, middle, and late Paleozoic crinoid faunas. Our data corroborate the hypothesis that predators targeted epibionts on camerate crinoids and anal sacs on advanced cladids and suggest that the replacement of shearing predators by crushing predators after the Hangenberg extinction affected the locations of spines in Mississippian camerates.
\end{abstract}

Valerie J. P. Syverson. Department of Geoscience, University of Wisconsin-Madison, Madison, Wisconsin 48105, U.S.A. E-mail: vsyverson@gmail.com

Carlton E. Brett. Geology Department, University of Cincinnati, Cincinnati, Ohio 45221, U.S.A.

E-mail: brettce@ucmail.uc.edu

Forest J. Gahn. Department of Geology, Brigham Young University-Idaho, Rexburg, Idaho 83460, U.S.A. E-mail: gahnf@byui.edu

Tomasz K. Baumiller. University of Michigan Museum of Paleontology, Ann Arbor, Michigan 48105, U.S.A. E-mail: tomaszb@umich.edu

Accepted: 21 November 2017

Data available from the Dryad Digital Repository: http:/ /dx.doi.org/10.5061/dryad.s7576

\section{Introduction}

Predation constitutes a substantial source of adaptive pressure on crinoids, and many researchers have hypothesized that it has been a primary driver of their morphological and ecological evolution (Signor and Brett 1984; Meyer 1985; Oji and Okamoto 1994; Baumiller et al. 2008; Baumiller and Gahn 2012; Syverson and Baumiller 2014). Although modern crinoids may autotomize arms during ontogeny (Roux 1976; Nakano et al. 2004; Obuchi et al. 2010) or under stress (Baumiller 2003b; Nichols 1996), modern stalked crinoids have few sources of injury other than predation (Mladenov 1983; Meyer 1985; Oji 1996; Lawrence 2009; Veitch et al. 2015), which is generally inferred to have been inflicted mainly by fishes (Meyer 1985; Waters and Maples 1991; Gahn and Baumiller 2010) and echinoids (e.g., Baumiller et al. 2008, 2010; Schneider 2001; Lach et al. 2015; Stevenson et al. 2017). Interactions between crinoids and their predators, including fish, echinoids, and asteroids, have occasionally been observed directly in modern ecosystems (Fishelson 1974; Meyer and Ausich 1983; Schneider 1988; Baumiller et al. 2008; Stevenson et al. 2017), as have crinoid remains in fecal material or gut contents of fishes (Meyer 1985; Baumiller et al. 2008). Injuries and regeneration in living specimens are observed much more frequently (Amemiya and Oji 1992; Donovan 1992; Carnevali et al. 1993; Oji 1996, 2001; Lawrence and Vasquez 1996; Lawrence 2009; Baumiller 2013b; Syverson et al. 2014). Stalked crinoids living in soft-bottom environments have few sources of injury other than predation, which increases with increasing 
predation stress, and therefore is negatively correlated with depth (Amemiya and Oji 1992; Baumiller 2013b; Veitch et al. 2016).

Regeneration frequency in modern crinoid populations reflects the presence and frequency of predation (Meyer and Macurda 1977; Bourgoin and Guillou 1994; Baumiller 2013b), and therefore damaged and regenerating body parts can be used to infer the intensity of predation on fossil crinoid populations as well (Oji 2001; Baumiller and Gahn 2004; Gahn and Baumiller 2005, 2010; Syverson et al. 2014). The regenerative capacity of echinoderms is such that crinoids have been observed recovering from injuries ranging from partial loss of a single arm to near-complete loss of the entire crown (Amemiya and Oji 1992; Oji 2001; Gahn and Baumiller 2010). Therefore, injuries observed in living or fossil specimens may have been caused by either lethal or nonlethal purpose, with either a lethal or a nonlethal result. Herein, we will instead use the terms "complete" and "partial" predation, thus addressing the physiological outcome for the crinoid only and avoiding discussion of predator strategy.

Previous studies have presented evidence, based on regeneration in both fossil and modern specimens, that crinoids have been subject to attacks since the Ordovician from a variety of predators, including fish, echinoids, gastropods, and possibly cephalopods and arthropods (e.g., Mladenov 1983; Waters and Maples 1991; Gahn and Baumiller 2010; Arendt 2012; Baumiller 2013b; Hess 2014; Syverson and Baumiller 2014). The mid-Paleozoic in particular has been characterized as a time of "marine revolution," that is, rapid intensification of predation and corresponding adaptive responses among prey, based on the diversity of potential predators, evidence of repaired and regenerated plates, and the occurrence of antipredatory adaptations. The Mid-Paleozoic Marine Revolution (MPMR) was originally described by Signor and Brett (1984) based on the widespread appearance of durophagous predators and defensive adaptations between the Silurian and the Mississippian. Subsequently, more evidence for an episode of escalating trophic interactions has been observed (Bambach 2002; Brett and Walker 2002; Brett 2003; Baumiller and Gahn 2004;
Kowalewski et al. 2005; Gahn and Baumiller 2010; Syverson and Baumiller 2014; Salamon et al. 2014). A major radiation of active predators, particularly placoderms and nautiloids, into the nekton and a corresponding decrease in the proportion of planktonic and demersal marine taxa occurred in the first half of the Devonian (Bambach 1999); this may have been related to a putative increase in oxygen availability (Berner 2006; Dahl 2010). Predatory injuries became progressively more common among camerate crinoids from the Ordovician to the Mississippian (Baumiller and Gahn 2004; Gahn and Baumiller 2010). However, no decline was observed in the occurrence of dense crinoid stands from the Ordovician/Silurian to the Mississippian after sedimentological correction, suggesting that increasing predation during the intervening period was not an important control on the frequency of such assemblages (Aronson 1991).

It has also been shown that some shifts in dominant crinoid traits over time can plausibly be construed as antipredatory adaptations that have been subject to evolutionary escalation (Meyer and Macurda 1977; Signor and Brett 1984; Oji and Okamoto 1994; Janevski and Baumiller 2010; Syverson and Baumiller 2014), although evidence for escalation in crinoids during the Devonian and Mississippian is equivocal (Syverson and Baumiller 2014; Thompson and Ausich 2015). Spines are the most commonly noted antipredatory adaptations associated with the MPMR, both in crinoids and in other shelly invertebrates. Several hypotheses hinging on the adaptive significance of spines in Paleozoic crinoids have been proposed; however, these have not yet been considered systematically with respect to temporal trends in spine occurrence. In this study, we address the following questions:

1. How do the intensities of partial predation in the two populations measured here (Middle Devonian Gennaeocrinus goldringae and late Paleozoic eucladids) compare with those in other populations already studied?

2. Do the spine occurrence patterns reject or corroborate the hypothesis that predators of cladids preferentially targeted anal sacs? 
3. Do the spine occurrence patterns reject or corroborate the hypothesis that the predators that injured camerates preferentially targeted infesting platyceratid gastropods?

4. Do the spine occurrence patterns reject or corroborate the hypothesis that the Mississippian camerate radiation was caused by predatory release after the Hangenberg extinction of Devonian predatory fishes with shearing jaws?

\section{Hypotheses}

Spine Regeneration Frequency.-Although accurately determining the precise adaptive function of fossil traits can be difficult, in many cases it is reasonable to assume functions based on the presence of similar structures in living organisms. Spines and other protrusions have multiple possible functions, but most proposals for their adaptive significance are antipredatory, including functions such as increasing effective body size (Johnsen et al. 2013), distributing force applied to the shell (Miller and Labarbera 1995), providing anchors for camouflage (Feifarek 1987), and disrupting the attachment of parasites and drillers (Leighton 2001). The functional morphology of spines depends heavily on their specific size and shape and is beyond the scope of this study. For the purposes of this study, all spines are treated as equivalent and as antipredatory, regardless of specific proposed functions.

Another test of crinoid spines' antipredatory function can be offered by examining spine injuries, given that interactions with durophagous predators should lead to occasional breakage. Unfortunately, spines could also be broken by postmortem processes and distinguishing nonpredatory from predatory breakages is challenging. However, regenerating spines provide evidence of interactions, and the prevalence of regenerating spines can be used as a measure of partial predation intensity (Baumiller 2013a). We take the presence of partially regenerated spines in a fossil population to indicate that crinoids survived one or more predatory encounters. Therefore, if the fossil crinoid populations studied here demonstrate frequencies of spine regeneration comparable to arm regeneration frequencies in modern populations, we will infer that they were subject to similar levels of partial predation.

Anal Sac Targeting.-Predators of many modern echinoderms seek out the highly nutritive gonads, which in some cases are heavily defended (Lowe 1979; Lucas et al. 1979; Nichols et al. 1982). In modern comatulids, the gonads are located on specialized pinnules on the arms, away from the visceral mass, and can be autotomized in response to predatory threats (Clark 1915; Nichols 1996), but among camerate crinoids, the gonads may have been inside the large thecae, as they were in one blastoid specimen (Katz and Sprinkle 1976), where predatory injury would pose a serious risk to the animal's survival (see Lane 1984). Lane (1984) suggested that the predators of Paleozoic crinoids may also have targeted the gonads and, thus, that the large anal sacs of some cladids functioned to keep the gonads in a location far from other vulnerable organs, similar to their autotomizable location on the arms of modern comatulids. The anal sac may have contained only other soft tissues such as the hindgut, and not the gonads (Kammer and Ausich 2007), but this could also present an appealing target to predators. In either case, if predators of cladids did target the anal sac, we expect that spines on the anal sac should be extremely common among the cladids as deterrents to fish predation and less common among those crinoids in which the anal structure was either absent or too narrow to house substantial volumes of soft tissue.

Platyceratid Targeting.-Previous authors have long noted an association between camerate crinoids and infesting platyceratid snails from the Middle Ordovician to the Permian (Clark 1915; Bowsher 1955; Rollins and Brezinski 1988; Morris and Felton 1993; Gahn and Baumiller 2003, 2006). Many genera of snails in the family Platyceratidae are commonly found in association with Paleozoic crinoids, usually camerates, generally located on the tegmen in the vicinity of the anus and commonly associated with deformations of the snail's growing margin or of the tegmenal surface, implying long-term residence. On this basis, it is generally supposed that the snail was in either a commensalistic or parasitic relationship with its crinoid host, in the 
former case being coprophagous and in the latter probably robbing food from the host's gut (kleptoparasitic). In some cases, attached platyceratids are associated with gastropod-type drill holes in the host's cup, indicating that these gastropods were capable of drilling through stereom (Baumiller 1990; Gahn et al. 2003). Whatever the precise trophic relationship, it appears to have been detrimental to some host populations, as infested crinoids were smaller than their uninfested conspecifics within three stands in three different populations of camerates (Rollins and Brezinski 1988; Gahn and Baumiller 2003). The evident preference of platyceratids for camerates appears to have been based on the presence of a relatively large tegmen that facilitated their attachment to the host (Bowsher 1955; Baumiller 2002; Brett 2003). Pinnulate arms, common in camerates and rare in other taxa during the middle Paleozoic, may also have increased food collected by these taxa and thus served to support a larger burden of parasites and commensals (Baumiller 1993).

Parasitic snail infestation increased in frequency from the Ordovician to the Mississippian (Baumiller 2003a; Gahn and Baumiller 2003, 2006). A particularly notable feature of many host crinoids from the Middle Devonian onward, but not before, is that many of them have spines on the dorsal cup, tegmen, or arms. Thus, as many spiny camerates (e.g., Arthroacantha) are among those most frequently infested by snails, it may be inferred that spines did not deter infestation. Instead, this association between spinosity and infestation has led to the hypothesis that an indirect interaction existed, in which parasitic platyceratids (as well as, potentially, other infesters with lower preservation potential for which there are no data) and not their camerate hosts were the target of predatory fishes. In this case, the camerates would still have sustained collateral damage from the predatory interaction. This has been termed the "targeting" hypothesis (Brett and Walker 2002; Brett 2003; Brett et al. 2004). In this scenario, the spines may have been an adaptation to predatory attacks on the crinoid's epibionts that indirectly resulted in injury to the crinoid.

Our data allow us to test the targeting hypothesis quantitatively. Under this hypothesis, we predict that the presence of spines in a camerate genus predicts its having an association with platyceratids. If this is the case, we expect to find a high correlation between spinosity and gastropod infestation in camerates, highest when infestation frequency is at its maximum. Furthermore, we expect tegmenal spines to have followed the same frequency pattern as infestation in camerates; that is, we expect tegmenal spines in camerates to increase in frequency until the Mississippian and then to become far less common during the period of cladid dominance in the Pennsylvanian and later. We also expect the association in camerates to be predicted primarily by spines located on the tegmen, the most common site of platyceratid infestation, and to a lesser extent by spines on the dorsal cup, where the snails are also sometimes present. In cladids, if platyceratids are present at all, they are usually located at the apex of the anal sac, so we would expect anal sac spinosity to correlate with infestation.

Early Mississippian Predatory Release.-The Hangenberg extinction of the Devonian durophagous fish fauna was followed by a radiation of new Carboniferous durophages in the Serpukhovian, corresponding to a transition from primarily shearing to primarily crushing jaw types (Sallan and Coates 2010). The camerate-dominated crinoid faunas of the early to middle Paleozoic are also distinct from the cladid-dominated ones of the late Paleozoic, with an intervening period of distinctively Mississippian camerates (see Fig. 1). Sallan et al. (2011) connected these two facts by hypothesizing that the interval between the two durophagous fish faunas, and the resultant relaxation of evolutionary pressure from shearing predation on crinoids, permitted the Early Mississippian camerate radiation and so-called "Age of Crinoids," and that the subsequent radiation of crushing predator morphotypes contributed to the Late Mississippian shift from camerate- to cladiddominated crinoid faunas. This dynamic is described as "predatory release."

However, although the removal of predators is reliably found to produce population explosions in modern systems, the immediate consequence of this is decreased rather 


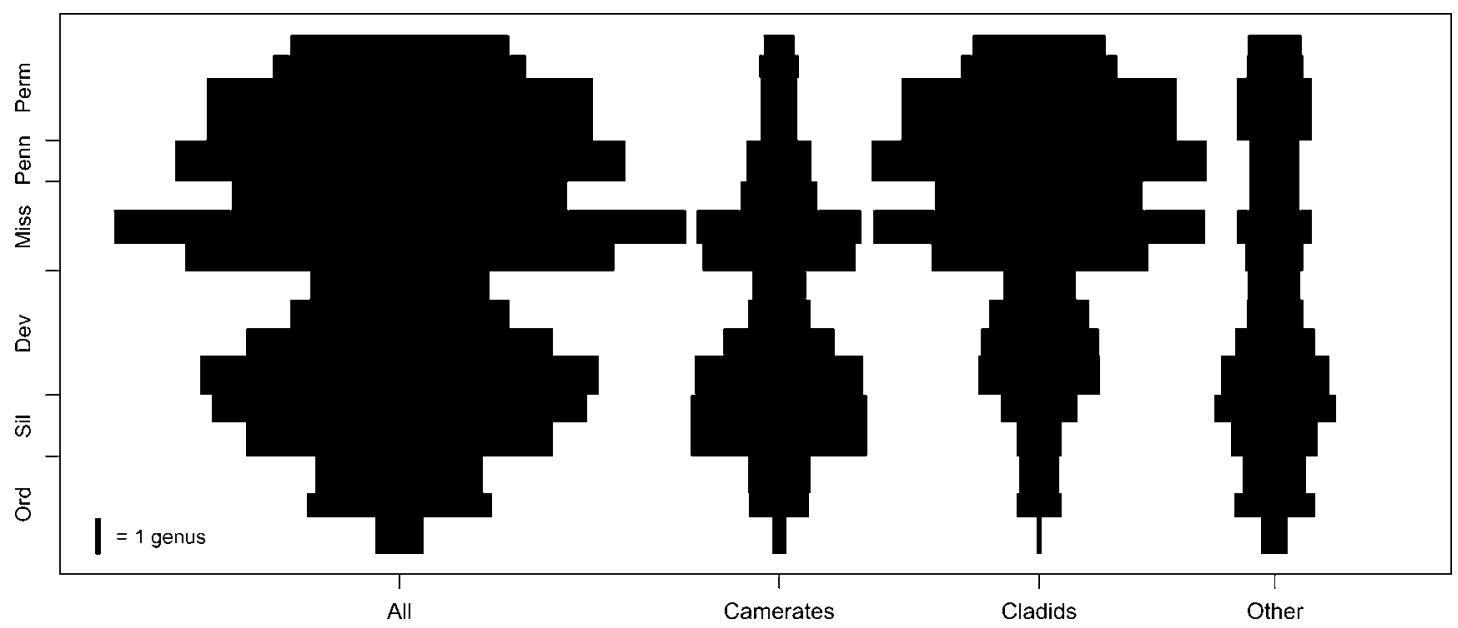

FIGURE 1. Spindle plots of genus-level Paleozoic crinoid diversity, separated into the taxonomic groups and time intervals used in this study. Scale bar gives the width of 1 genus. Dev, Devonian; Miss, Mississippian; Ord, Ordovician; Penn, Pennsylvanian; Perm, Permian; Sil, Silurian.

than increased diversity; indeed, the presence of predation in conjunction with competition is generally known to promote diversity at various ecological scales (e.g., Paine 1966; Terborgh 2015). If predatory pressure did indeed suppress crinoid diversification before the end-Devonian extinction, as described by the predatory release hypothesis, then the ecological conditions of the system in this interval were very different from those found in modern experiments, whether for timescalerelated reasons or as a result of non-analogue ecological conditions. In this case, the applicability of the concept of escalation to this interval may need to be reconsidered.

Our data allow the testing of this hypothesis. If predatory pressure had been suppressing camerate speciation during the late Devonian, and the relaxation of this constraint allowed a radiation to take place, as suggested, then the new camerate taxa of the Early Mississippian would have originated during a time of low predation, and we might therefore expect them to have the same or a smaller proportion of spiny taxa as compared with those that originated during the Middle Devonian or Late Mississippian peaks in durophagous fish diversity. Additionally, if the hypotheses described earlier regarding predator targeting of gonads and parasites are supported, we would expect this to be particularly true of camerate calyces and cladid anal sacs.

\section{Data Collection and Analysis}

In this study, we present two, separate, new data sets pertaining to predation frequency and spinosity in Paleozoic crinoids, as follows.

Spine Breakage and Regeneration Frequencies.These data consist of measurements of breakage and regeneration frequency on a small sample $(n=176)$ of disarticulated spine ossicles from the Middle Devonian Bell Shale of Michigan, reposited at the University of Michigan Museum of Paleontology (UMMP), probably derived from the dorsal cup and tegmen of the monobathrid Gennaeocrinus goldringae (Fig. 2A), although no articulated specimen was found to confirm the diagnosis (Kesling 1965). The measurements taken were width and depth at the base of each spine; length from the base to the point of regeneration, if applicable; length from the base to the point of breakage, if applicable; and total spine length. Spines were sorted by anatomical location, by whether they were broken, and by whether the broken spine was visibly regenerating.

A similar analysis was conducted for a much larger set of disarticulated spines of cladids from the Middle Pennsylvanian through the early Permian $(n=1178 ; 430$ anal sac spines, 748 cup spines; Table 1). These specimens, also reposited at the UMMP, were collected by R. C. Moore and R. S. Jeffords from several locations in the southern Great Plains of North America, paleogeographically the shelf of the Pennsylvanian 
A
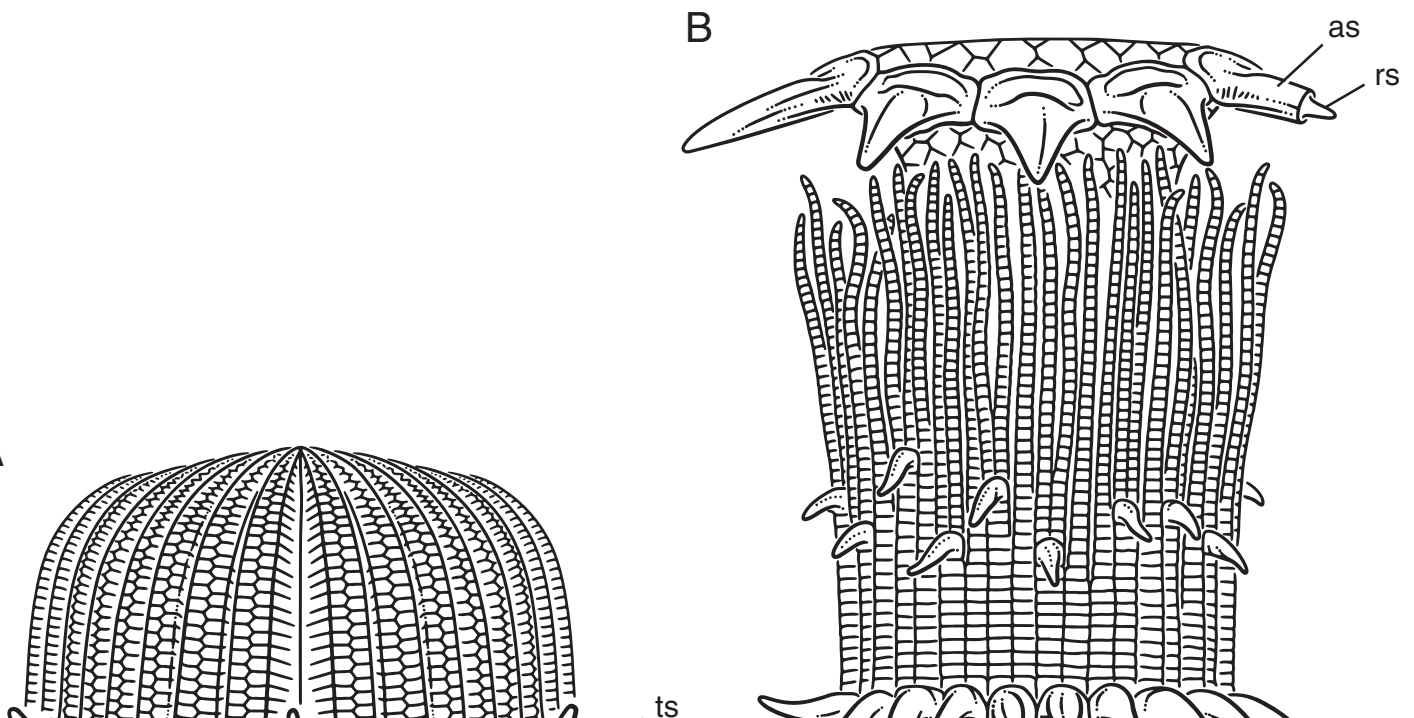
rs

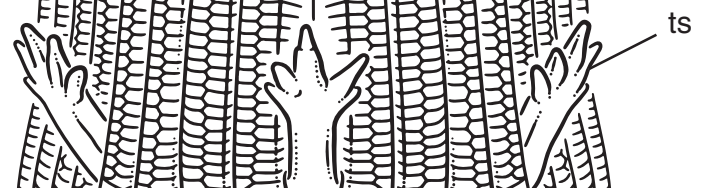

ts

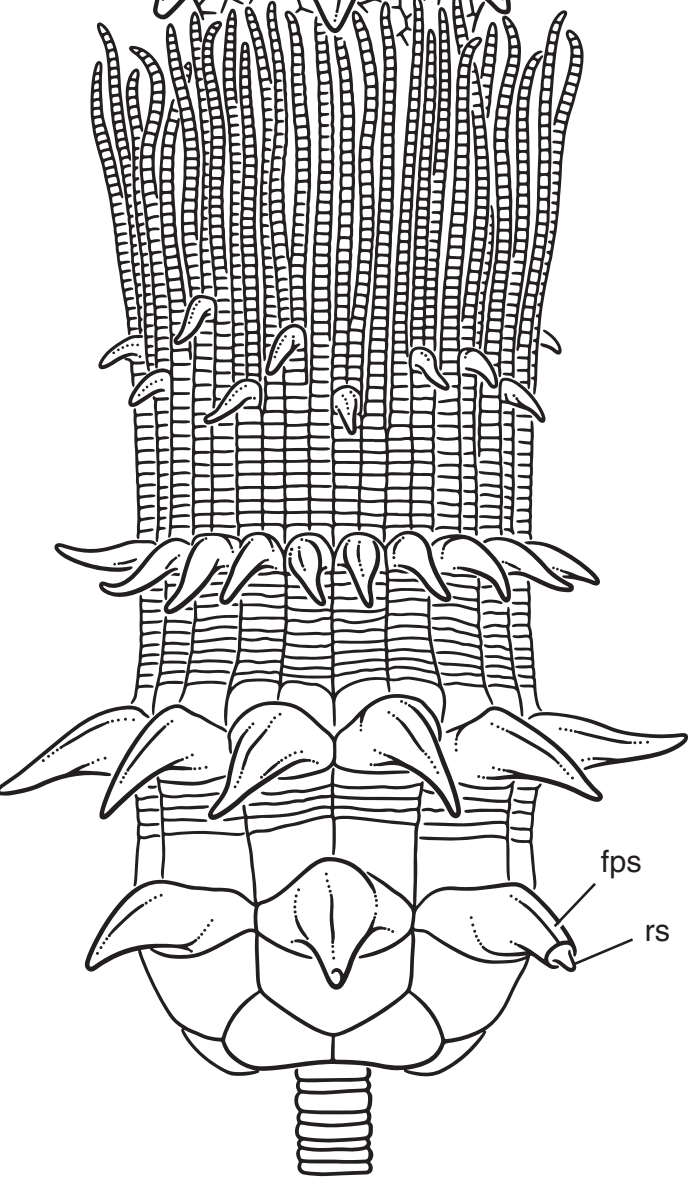

C
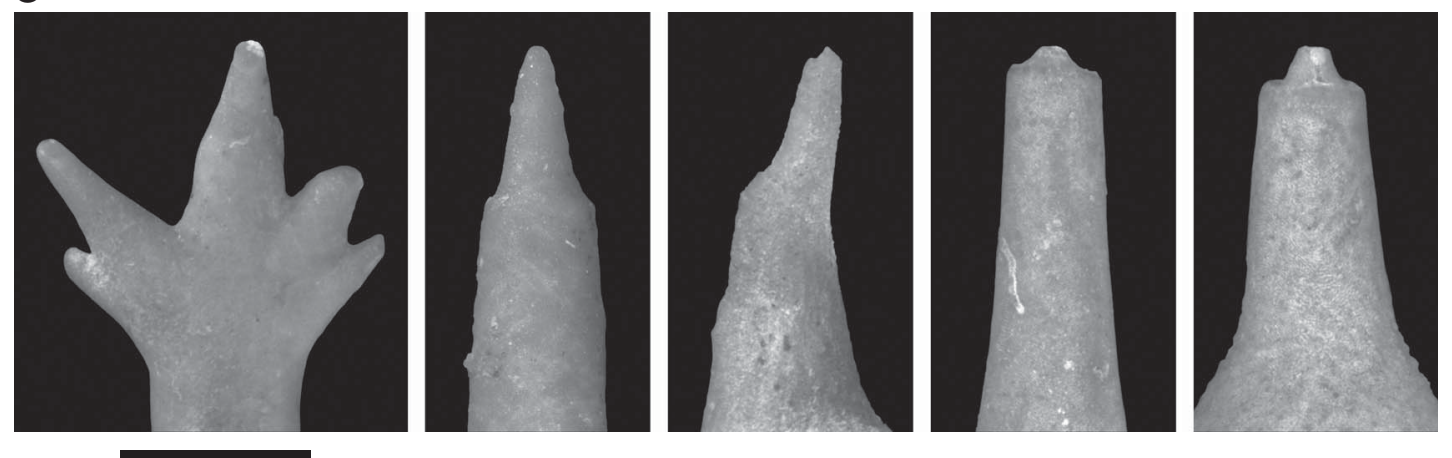

FIGURE 2. Schematic drawings of crinoid taxa for which spine breakage and regeneration rates were assessed and examples of regenerated spines for each. A, Gennaeocrinus goldringae after Kesling (1965). Labels: ts, tegmen spine; dcs, dorsal cup spine; rs, regenerating spine. B, Generalized eucladid ("pirasocrinid") similar to those present in the late Paleozoic sample. Labels: as, anal spine; fps, first primibrach spine; rs, regenerating spine. C, Examples of regenerating spines. From left: G. goldringae tegmen spine, G. goldringae tegmen spine, G. goldringae dorsal cup spine, "pirasocrinid" first primibrach spine, "pirasocrinid" anal spine. Scale bar, $4 \mathrm{~mm}$ for leftmost G. goldringae tegmen spine; $2 \mathrm{~mm}$ for the four others. 
Midcontinental Sea (Algeo and Heckel 2008), and published as part of a monograph on fragmentary crinoid remains (Moore and Jeffords 1968). Genus-level taxonomy could not be ascertained reliably, but all specimens measured are from cladid crinoids, probably within the Eucladida sensu Wright et al. (2017). A generalized cladid of the type present in this sample is shown in Figure 2B. This taxonomic uncertainty makes it impossible to use a comparison of the regeneration frequencies between anal sac spines and cup spines to assess which part sustained more frequent damage, because the number of each spine type present per individual is uncertain and probably variable.

An example of a partially regenerated anal spine from the late Paleozoic cladid sample is shown in Figure 2C. Many of the examined spines were broken without any sign of healing or regeneration at the broken surface, which we interpreted as indicating peri- or postmortem damage. These specimens would artificially lower the observed frequency of regenerating injuries $\left(R_{\mathrm{obs}}\right)$, because the broken-off, unrecovered distal portions of those spines, which might have been regenerating from a previous injury before they were lost, would not be reported as partially regenerated. To correct for this downward bias, observed regeneration frequency was adjusted based on an estimate of the original prebreakage lengths of the spines, which was estimated from the geometry of any intact specimens in the sample. For example, if a sample experienced postmortem damage such that, on average, the recovered spines were $75 \%$ of their original length (completeness, $\mathrm{C}=0.75$ ), and $R_{\mathrm{obs}}$ in that sample is 0.1 , then if we assume that the regeneration frequency on the missing portions of the spines was the same as that of the recovered portions, the true regeneration frequency is $R_{\mathrm{obs}} /$ $\mathrm{C}=0.13$. Adding a step where breakage and regeneration values were bootstrapped from observed distributions yielded very similar estimates of $R_{\text {true, }}$ so the simpler model was used.

Spinosity and Infestation Data.-A compilation of the taxonomy and stratigraphic range of all crinoid genera with spines was made for the purposes of identifying the timing of the MPMR in the paper that defined that event (Signor and Brett 1984). Herein, we have compiled an updated and more comprehensive data set based on similar sources, primarily the Treatise on Invertebrate Paleontology and museum collections, with added detail on the spines' anatomical location. Temporal ranges and taxonomy for Paleozoic genera were taken from Webster's compendium (Webster 2013), and the taxonomic diversity through time is illustrated as a spindle plot in Figure 1.

Data were compiled on the presence and location of spines in crinoids during the Paleozoic, based on figures and genus descriptions in the volume of the Treatise on Invertebrate Paleontology on Paleozoic crinoids and figures from monographs on camerates and flexibles (Wachsmuth and Springer 1897; Springer 1920; Moore et al. 1978). For the Treatise, all descriptions including forms of the word "spine" and all visibly spiny specimens in figures were tabulated; in Springer's monographs, only the figures were used. This survey yielded a total of 100 genera with any kind of spines. A further five genera were added based on spiny specimens in the UMMP invertebrate collection. In addition, the presence/absence and location of spines, the presence/absence of anal sacs, and the occurrence of platyceratid hosts were tabulated in assemblages of contemporaneous pelmatozoans in the Silurian and Devonian to test for patterns of distribution and co-occurrence. Anatomy was tabulated from descriptions and figures; spines associated with the anus were coded as "tegmen," except where an anal tube or sac elevated them above the oral surface, and spines on the first free brachial were coded as "cup," while those on any higher free brachial were coded as "arms." The presence of anal sacs or tubes was also cataloged based on genus descriptions (Moore et al. 1978). For comparison, Signor and Brett (1984) recorded the number of genera in the collections of Macurda and Springer (both now at the U.S. National Museum) and in figures from Springer's monographs and the Treatise on Invertebrate Paleontology for which any individual had sharp projections of any kind, and the locations of those spines (cup, arms, or anal tube/sac), not including nodules and tubercles.

Platyceratid occurrence was tabulated from the work of Kluessendorf (1983) for Silurian and from illustrations in Goldring (1923) for Devonian crinoids, from previous work 
by Gahn and Baumiller (2006), and from observations (by C.E.B.) of specimens in the U.S. National Museum, the American Museum of Natural History, the University of Michigan, and the large collections of Dr. George C. McIntosh (Rochester Museum and Science Center).

\section{Results}

Spine Regeneration Frequencies.-These data are summarized in Table 2 and illustrated in Figure 3; the full data set is given in Supplementary Table A.

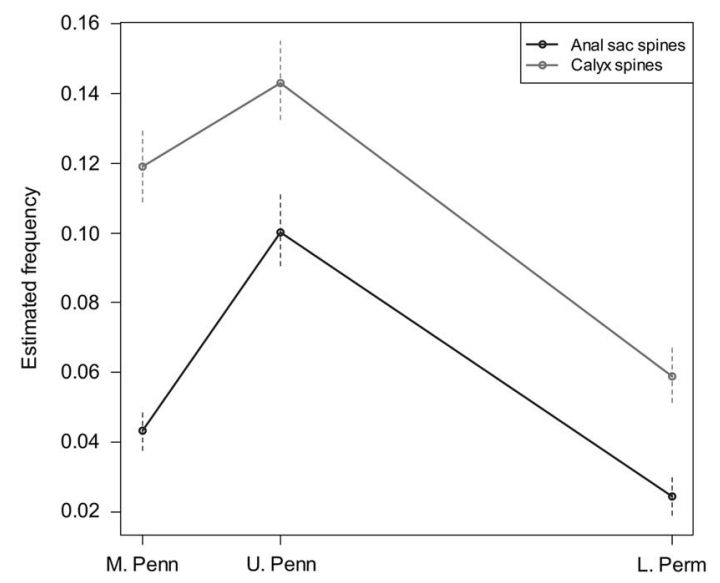

FIGURE 3. Estimated true regeneration frequencies for anal and primibrach spines from Middle Pennsylvanian, Late Pennsylvanian, and early Permian eucladid assemblages, separated by time period. Significance intervals indicated are $\pm 1 \mathrm{SE}$.
The frequency of regeneration in the Devonian Gennaeocrinus sample was $9 \%$ for the straight calycal spines and $20 \%$ for the branching tegmenal spines. However, the unusual branching form of the tegmenal spines makes it impossible to perform the adjustment for postmortem breakage, and in many specimens the evidence for regeneration was ambiguous, so this estimate should be regarded as less reliable than the values for the late Paleozoic sample.

In the late Paleozoic sample taken as a whole, $98 \%$ of spines were broken. When these values are adjusted for postmortem breakage following the above procedure, the estimated true regeneration frequencies are $7.9 \%$ for all spines; separated by anatomy, this is $9.4 \%$ for first primibrachial spines and $6.2 \%$ for anal sac spines, with the former more frequently broken in all intervals. Estimated true regeneration frequencies separated by time (Middle Pennsylvanian, Late Pennsylvanian, and early Permian) are given in Table 1 and shown in Figure 3. Between $5 \%$ and $15 \%$ of spines have evidence of regeneration in all time intervals and localities sampled for the Pennsylvanian and Permian, indicating that these crinoids were subject to substantial levels of partial predation during the late Paleozoic. The regeneration frequencies in the Devonian samples fall within the same range.

Spinosity and Infestation.-These results are summarized in Table 2 and illustrated in

TABLE 1. Regeneration frequencies for populations of disarticulated spines. The observed regeneration frequency and distribution of breakage locations were used to infer the true frequency of nonlethal damage in the living population.

For details on the method of estimation, see text.

\begin{tabular}{|c|c|c|c|c|c|c|}
\hline Age & Taxon & $\begin{array}{c}\text { Anatomical } \\
\text { type }\end{array}$ & $n$ & $\begin{array}{c}\text { Observed } \\
\text { breakage } \\
\text { frequency }(\%)\end{array}$ & $\begin{array}{c}\text { Observed } \\
\text { regeneration } \\
\text { frequency }(\%)\end{array}$ & $\begin{array}{l}\text { Estimated true } \\
\text { regeneration } \\
\text { frequency }(\%)\end{array}$ \\
\hline \multirow[t]{2}{*}{ Early Permian } & Eucladida & Anal sac & 157 & 100 & 1.9 & 2.4 \\
\hline & & 1st primibrach & 232 & 96.3 & 4.7 & 5.6 \\
\hline \multirow[t]{2}{*}{ Late Pennsylvanian } & Eucladida & Anal sac & 211 & 99.5 & 7.6 & 9.9 \\
\hline & & 1st primibrach & 12 & 100 & 8.3 & 14.5 \\
\hline \multirow{2}{*}{ Middle Pennsylvanian } & Eucladida & Anal sac & 54 & 98.1 & 3.7 & 4.2 \\
\hline & & 1st primibrach & 460 & 96.3 & 10 & 12 \\
\hline \multirow[t]{3}{*}{ Pennsylvanian to Permian } & Eucladida & All & 1126 & 97.8 & 6.8 & NA \\
\hline & & Anal sac & 422 & 99.5 & 4.9 & 6.2 \\
\hline & & 1st primibrach & 704 & 96.8 & 7.9 & 9.4 \\
\hline \multirow[t]{3}{*}{ Middle Devonian } & Gennaeocrinus & All & 176 & 59.1 & 12.5 & NA \\
\hline & goldringae & Tegmen (oral) & 60 & 53.3 & 20 & NA \\
\hline & & Calyx (aboral) & 116 & 62.1 & 8.6 & NA \\
\hline
\end{tabular}


TABLE 2. Summary of the number of genera with spines and the number known to have been infested by platyceratid gastropods, separated by time interval.

\begin{tabular}{|c|c|c|c|c|c|c|c|c|c|}
\hline \multirow[b]{2}{*}{ Period } & \multirow[b]{2}{*}{ Taxon } & \multirow[b]{2}{*}{$\begin{array}{l}\text { Total } \\
\text { genera }\end{array}$} & \multirow[b]{2}{*}{$\begin{array}{l}\text { Has anal } \\
\text { sac/tube }\end{array}$} & \multirow[b]{2}{*}{$\begin{array}{c}\text { Platyceratid } \\
\text { host }\end{array}$} & \multicolumn{5}{|c|}{ Spines } \\
\hline & & & & & Any & $\begin{array}{l}\text { Dorsal } \\
\text { cup }\end{array}$ & Tegmen & Arms & $\begin{array}{c}\text { Anal } \\
\text { structure }\end{array}$ \\
\hline \multirow[t]{3}{*}{ Early Ordovician } & Camerates & 6 & 0 & 0 & 0 & 0 & 0 & 0 & 0 \\
\hline & Cladids & 3 & 1 & 1 & 0 & 0 & 0 & 0 & 0 \\
\hline & Other & 12 & 0 & 0 & 0 & 0 & 0 & 0 & 0 \\
\hline \multirow[t]{3}{*}{ Middle Ordovician } & Camerates & 26 & 1 & 2 & 0 & 0 & 0 & 0 & 0 \\
\hline & Cladids & 20 & 4 & 2 & 0 & 0 & 0 & 0 & 0 \\
\hline & Other & 36 & 7 & 0 & 1 & 1 & 0 & 0 & 0 \\
\hline \multirow{3}{*}{ Late Ordovician } & Camerates & 28 & 3 & 6 & 1 & 0 & 1 & 0 & 0 \\
\hline & Cladids & 18 & 5 & 2 & 0 & 0 & 0 & 0 & 0 \\
\hline & Other & 28 & 12 & 0 & 0 & 0 & 0 & 0 & 0 \\
\hline \multirow{3}{*}{ Llandovery } & Camerates & 78 & 7 & 12 & 6 & 3 & 4 & 0 & 1 \\
\hline & Cladids & 20 & 6 & 2 & 1 & 1 & 0 & 0 & 0 \\
\hline & Other & 38 & 5 & 0 & 0 & 0 & 0 & 0 & 0 \\
\hline Wenlock/Ludlow/ & Camerates & 78 & 8 & 11 & 7 & 3 & 5 & 0 & 1 \\
\hline \multirow[t]{2}{*}{ Pridoli } & Cladids & 34 & 10 & 3 & 3 & 1 & 0 & 0 & 2 \\
\hline & Other & 54 & 8 & 0 & 0 & 0 & 0 & 0 & 0 \\
\hline \multirow[t]{3}{*}{ Early Devonian } & Camerates & 74 & 13 & 18 & 15 & 9 & 12 & 4 & 0 \\
\hline & Cladids & 54 & 9 & 2 & 3 & 1 & 0 & 0 & 2 \\
\hline & Other & 48 & 3 & 0 & 0 & 0 & 0 & 0 & 0 \\
\hline \multirow[t]{3}{*}{ Middle Devonian } & Camerates & 49 & 12 & 16 & 17 & 12 & 13 & 3 & 1 \\
\hline & Cladids & 52 & 10 & 2 & 3 & 2 & 0 & 0 & 1 \\
\hline & Other & 35 & 3 & 1 & 3 & 2 & 0 & 2 & 0 \\
\hline \multirow{3}{*}{ Frasnian } & Camerates & 28 & 8 & 11 & 9 & 8 & 7 & 3 & 1 \\
\hline & Cladids & 44 & 9 & 2 & 3 & 1 & 0 & 1 & 1 \\
\hline & Other & 25 & 2 & 1 & 4 & 3 & 0 & 3 & 0 \\
\hline \multirow[t]{3}{*}{ Famennian } & Camerates & 24 & 8 & 11 & 9 & 8 & 7 & 3 & 1 \\
\hline & Cladids & 32 & 8 & 2 & 3 & 1 & 0 & 1 & 1 \\
\hline & Other & 23 & 2 & 1 & 4 & 3 & 0 & 3 & 0 \\
\hline \multirow[t]{3}{*}{ Tournaisian } & Camerates & 68 & 21 & 24 & 26 & 12 & 22 & 5 & 8 \\
\hline & Cladids & 96 & 23 & 4 & 11 & 2 & 0 & 1 & 8 \\
\hline & Other & 26 & 4 & 1 & 3 & 2 & 0 & 3 & 0 \\
\hline \multirow[t]{3}{*}{ Viséan } & Camerates & 73 & 22 & 27 & 29 & 12 & 25 & 5 & 8 \\
\hline & Cladids & 147 & 37 & 5 & 25 & 5 & 1 & 5 & 22 \\
\hline & Other & 33 & 4 & 1 & 4 & 3 & 0 & 3 & 0 \\
\hline \multirow[t]{3}{*}{ Serpukhovian } & Camerates & 34 & 9 & 11 & 11 & 6 & 10 & 1 & 2 \\
\hline & Cladids & 92 & 24 & 4 & 17 & 5 & 1 & 4 & 15 \\
\hline & Other & 22 & 3 & 1 & 3 & 2 & 0 & 2 & 0 \\
\hline \multirow[t]{3}{*}{ Pennsylvanian } & Camerates & 29 & 4 & 5 & 4 & 4 & 4 & 1 & 1 \\
\hline & Cladids & 148 & 36 & 5 & 26 & 6 & 1 & 9 & 23 \\
\hline & Other & 22 & 2 & 0 & 2 & 2 & 0 & 0 & 0 \\
\hline Cisuralian & Camerates & 16 & 3 & 5 & 3 & 2 & 3 & 0 & 1 \\
\hline & Cladids & 122 & 14 & 3 & 12 & 4 & 1 & 5 & 7 \\
\hline & Other & 33 & 0 & 0 & 1 & 1 & 0 & 0 & 0 \\
\hline Guadalupian & Camerates & 18 & 3 & 5 & 3 & 2 & 3 & 0 & 1 \\
\hline & Cladids & 69 & 5 & 2 & 3 & 1 & 0 & 1 & 2 \\
\hline & Other & 25 & 0 & 0 & 0 & 0 & 0 & 0 & 0 \\
\hline Lopingian & Camerates & 14 & 2 & 5 & 3 & 2 & 3 & 0 & 1 \\
\hline & Cladids & 59 & 5 & 2 & 2 & 0 & 0 & 1 & 2 \\
\hline & Other & 24 & 0 & 0 & 0 & 0 & 0 & 0 & 0 \\
\hline
\end{tabular}

Figure 4; the full data set is given in Supplementary Table B.

Spinosity in camerates increases steadily from the Ordovician into the Middle Devonian, remains common (up to $40 \%$ of taxa) through the Late Mississippian, and drops off abruptly to $14 \%$ in the Pennsylvanian. There is a sharp distinction between spines on the dorsal cup, which become less common after the DevonianMississippian transition (going from 33\% to $18 \%$ ), and tegmenal spines, which continue to be common until the end of the Mississippian. In cladids, spines are much more common from the mid-Mississippian through the Pennsylvanian 

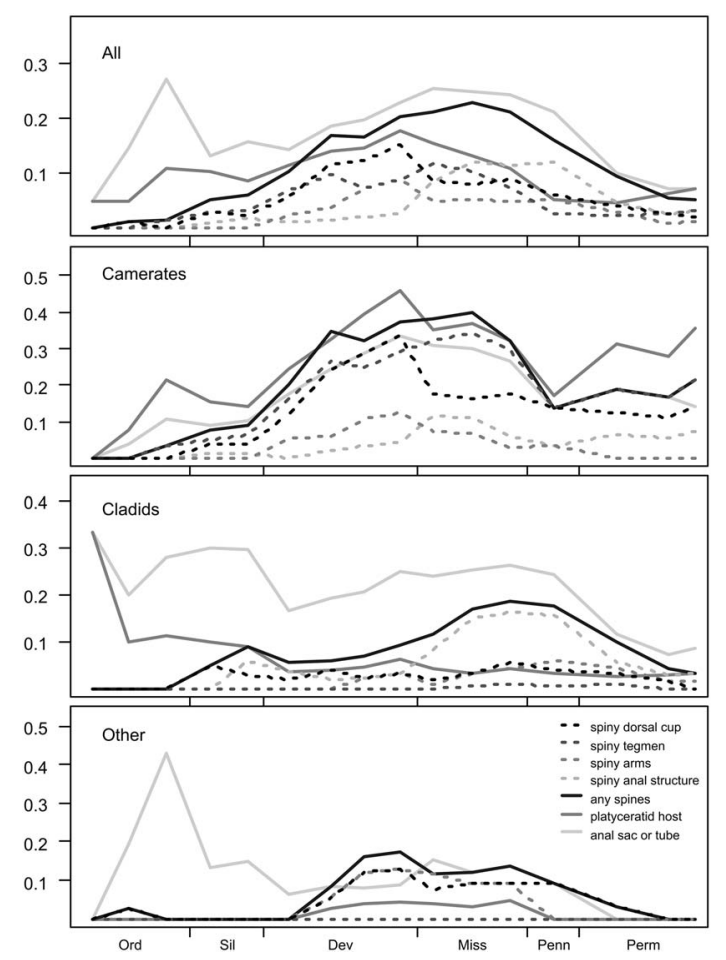

FIGURE 4. Proportion of the crinoid genera present in each interval with the following properties: having spines on different body parts; having spines anywhere on the body; having an elevated anal structure; and hosting platyceratid snails as epibionts. From top to bottom: all genera; Camerata; Cladida; and all others, consisting mainly of Flexibilia and Disparida.

than at any other time; this pattern is mostly driven by spines on the anal sac, which are present on almost all (67-88\%) of the spiny cladid genera during this interval.

Among Ordovician and Silurian platyceratidcrinoid pairs, we find that almost none of the host taxa are spiny $(<10 \%$ in all pre-Devonian intervals), and indeed less than $10 \%$ of crinoids during this interval bore spines. In the bestknown Ordovician collections from the Trenton Group and the Cincinnatian, there are about 22 genera of crinoids and 5 of rhombiferans. In this group, four genera are known to act as hosts to the early platyceratid gastropod Cyclonema, but none of these or any other crinoids in the Ordovician of North America have spines on the dorsal cup, tegmen, or arms. In the most densely infested populations, about $25 \%$ of individuals of Pycnocrinus or Glyptocrinus have a Cyclonema attached. In the Silurian, both Naticonema and the newly evolved Platyceras are present on crinoids, mainly camerates, including Dimerocrinites, Macrostylocrinus, and large Periechocrinus, as well as the rhombiferan Caryocrinites. A total of about 7 of the approximately 40 genera of pelmatozoans present were selectively infested by platyceratids; no other forms served as hosts. Frequency of infestation is relatively low in most samples, with fewer than $1 \%$ of individuals hosting platyceratids.

Among 20 genera of crinoids and 3 rhombiferans from the best-known Wenlock assemblages of the Rochester Shale of New York and the Waldron Shale in Indiana, 5 known genera of camerates and the rhombiferan Caryocrinites served as hosts of platyceratid gastropods. The common feature of the hosts is that they all have a relatively broad tegmen, often with a distinct small anal tube. The camerate look-alike rhombiferan Caryocrinites, the only infested non-crinoid, also had a broad tegmen. None of these pelmatozoans had spines. Indeed, only one contemporaneous, rather large camerate, Calliocrinus, is spinose, and it has not been reported as a platyceratid host.

Middle Devonian pelmatozoans from North America reveal a very different scenario. Collections from Eifelian and Givetian strata, including the well-known Onondaga Formation and Hamilton Group of New York State, and equivalent Detroit River Formation and Traverse Group of northern Ohio and Michigan, yield a total of 70 genera of crinoids, 10 blastoids, and 1 rhombiferan (G. C. McIntosh and C. Brett, unpublished data). Of these, 10 crinoid genera are known to have hosted platyceratid gastropods, including both Platyceras and Naticonema. Relative to Silurian collections, a notably greater proportion of crinoid genera $(17 \%)$ possess spines on the dorsal cup, tegmen, and/or axillaries of the arms.

A total of about 50 genera of crinoids are known from the Givetian Hamilton Group in New York and equivalent Silica of Ohio and Arkona Shale of Ontario (uncertainties reflect taxonomic placement of a few taxa into new genera). These include eight genera that are known to exhibit attached platyceratids, at least rarely. Four of these are heavily infested. For example, in certain large populations of Arthroacantha, such as those from the Arkona 
Shale of Ontario, more than $90 \%$ of individuals may be infested by platyceratids (Gahn and Baumiller 2006). These include a predominance of Spinoplatyceras with spines up to $4 \mathrm{~cm}$ long. In Devonian collections, the majority of host crinoid genera also have spines on the dorsal cup, tegmen, and/or arms. Arthroacantha, the most heavily infested of all genera, has movable spines on the dorsal cup and fixed spines on the axillaries of the arms. Even more significant is that, among the remaining "non-host" group, none are spiny, with the exception of a few cladids that have spines on their anal sacs. The trend continues into the Mississippian, when an even larger cohort of 27 camerate genera hosted platyceratids, 20 of them spiny.

\section{Discussion of Hypotheses and Implications of New Data}

Predation Pressure in the Devonian and Late Paleozoic.-Comparison of the spine regeneration frequencies in this sample to those from other populations is complicated by the variable ways in which injury frequency is reported. The regeneration frequencies per individual reported in many publications are difficult to compare with the frequencies per part measured here, especially since the disarticulated and taxonomically unspecific nature of the cladid material means we do not know the number of parts (spines on anal sacs and cups) per individual, due to the variation within the set of species potentially present. However, a few authors have reported injury frequencies per arm, and the values in our sample are similar to the highest known such estimates in shallow-water crinoid populations from the Paleozoic, such as that of Rhodocrinites kirbyi (in which 75 of 970 examined arms were partially regenerated, i.e., 7.7\%) from the Tournaisian crinoid Lagerstätte at Le Grand, Iowa (Gahn and Baumiller 2005), and to the lower end of estimates from living populations, such as Florometra serratissima at depths between $79 \mathrm{~m} \mathrm{(18 \% )}$ and $209 \mathrm{~m}(4 \%)$ (Baumiller 2013a) and Endoxocrinus sp. from $>500$ m (14\%) (Oji 1996).

As no mechanism other than predation has actually been demonstrated to damage the crowns of crinoids, as discussed earlier, we assume that they were broken in nonfatal interactions with predators (Baumiller and Gahn 2003; Gahn and Baumiller 2005, 2010; Syverson and Baumiller 2014; Syverson et al. 2014). The two samples are bathymetrically similar (Kesling 1965; Moore and Jeffords 1968), and furthermore, the bathymetric gradient in predation intensity is thought to be a post-Mesozoic pattern (Oji 1996; Baumiller 2013a). Partial predation appears to have been at moderately high levels in populations during the Middle Devonian and from the middle Pennsylvanian through the early Permian, suggesting that partial predation applied a relatively consistent selective pressure on shallow-water crinoid populations in North American midcontinental seas during the latter half of the Paleozoic.

Anal Sac Targeting.-If the gonadal and visceral tissues were the preferred food of Paleozoic predators, with the anal sac in cladids serving to place this high-value target farther from the rest of the body, as suggested by Lane (1984), the expected pattern would be that anal sacs were reliably spiny. It is notable that the proportion of crinoids with anal sacs increases from the early Paleozoic into the Devonian: about $20 \%$ of Devonian cladid genera possessed anal sacs or tubes, but only $4 \%$ (four genera) had spines on the anal sacs. The anal sac is by far the most common location for spines in later cladids, and the proportion of cladids with anal sac spines peaks during their radiation in the Late Mississippian and Pennsylvanian: during the Famennian, $12.5 \%$ of cladids with anal sacs had spines on them, in the Tournaisian this rose to $35 \%$, and from the Viséan through the early Permian was $50-65 \%$. For comparison, no more than $5.5 \%$ of cladids in any interval had spines on the dorsal cup or arms. This result is consistent with the hypothesis that the anal sac was a persistent target of cladids' predators, far more than any other part of the body. For the reasons described earlier, it is not possible to assess this hypothesis using the regeneration data collected in this study. We predict that injured and partially regenerated intact anal sacs should be more common in those cladid taxa in which they are not protected by spines; no data have been collected to test this, although specimens with partially regenerated anal sacs exist (Gahn and Baumiller 2005, 2010). 


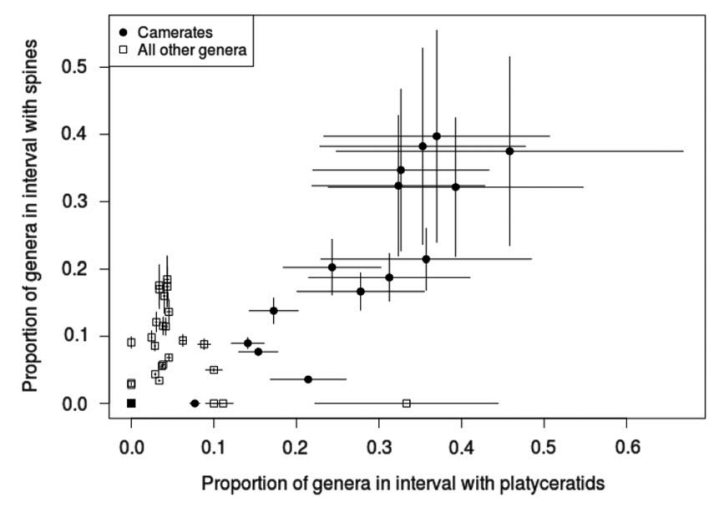

FIGURE 5. Proportion of crinoid genera hosting platyceratid gastropod epibionts vs. proportion with spines in each time interval for the Paleozoic, with camerates and non-camerates separated. Error bars indicate \pm 1 SE. The proportion of spiny genera and that of infested genera are well correlated for camerates, but no relationship between spinosity and infestation is evident for any other taxon.

Platyceratid Targeting.-We predicted that, if the targeting hypothesis is correct, tegmen spinosity and gastropod infestation should be correlated in camerates. This prediction is validated by our data, indicated by a chi-square test $\left(\chi^{2}: 9.04, p=0.004\right.$ with $\left.1 \mathrm{df}, N=199\right)$. However, overall spinosity does not predict infestation $\left(\chi^{2}: 1.66, p=0.68\right.$ with $\left.1 \mathrm{df}, N=225\right)$, nor does presence of spines on the dorsal cup $\left(\chi^{2}: 2.93, p=0.087\right.$ with $\left.1 \mathrm{df}, N=225\right)$, despite the occasional occurrence of platyceratids there. In cladids, although only 10 genera overall were infested and no more than 5 in any interval, anal sac spinosity still predicts infestation $\left(\chi^{2}: 4.94\right.$, $p=0.039$ with $1 \mathrm{df}, N=79$ ).

The pattern of tegmenal spines in camerates overall also follows the predicted trajectory. The proportion of camerate genera with spines within each interval is highly correlated with the number of infested genera (Fig. 5), most of these being tegmen spines; they were as common in camerates of the Early Mississippian radiation as in their Devonian predecessors, and they do not decrease significantly in frequency until the Late Mississippian, which mirrors the pattern of host diversity reported by Gahn and Baumiller (2003). The only significant differences in values of tegmenal spine frequency in camerates occurred from the Middle Ordovician to Silurian and from the Middle Devonian through Viséan. However, this is not the case for anal sac spines in cladids, which suggests that platyceratid-related predation was not the major source of anal sac injury.

The high correlation between tegmenal spines and infestation makes it seem unlikely that their purpose was to keep platyceratids from settling on the tegmen, but quite plausible that they served to repel those predators drawn by the presence of these infesting mollusks. Furthermore, lower expected arm loss (Oji and Okamoto 1994; Syverson and Baumiller 2014) is associated with the presence of tegmenal spines $(N=47$, odds ratio $=0.131, p=0.04)$ in camerates. Thus, the data reported here favor the interpretation that one function of tegmenal spines in camerates, and to a lesser extent anal spines in cladids, was to repel predators targeting platyceratids. Further investigation of this hypothesis will include looking for direct evidence of predation on parasitic platyceratids in the form of damaged, repaired, or fragmented platyceratid shells in association with crinoids.

Predatory Release.-If predatory release after the Hangenberg extinction of durophagous fishes was a major factor governing the reradiation of the camerates during the Tournaisian, as suggested by Sallan et al. (2011), the new camerate taxa originating during the period between the extinction of the Devonian predatory fish fauna and the rise of the new Carboniferous predatory fish fauna should have been under decreased predatory pressure. If our assumption that spines serve an antipredatory function is correct, and if the signal can be observed on this temporal and taxonomic scale, we would expect fewer of these new genera to have spines than in cohorts originating in other intervals. This is not what is observed in this data set, as is apparent from Figure 6. Rather, the cohorts of camerate genera originating during the Tournaisian and Viséan have the second-highest and highest proportions of spiny genera, respectively, of the entire data set $(0.19 \pm 0.03$ of $n=143$ and $0.24 \pm 0.05$ of $n=74$ ). This is concordant with the high levels of Mississippian predation pressure reported in previous studies. It also coincides with a switch from predominantly shearing to predominantly crushing predation (Sallan 2013; Salamon et al. 2014). The lowest levels of spinosity instead occur in the Frasnian, although some camerates from the 


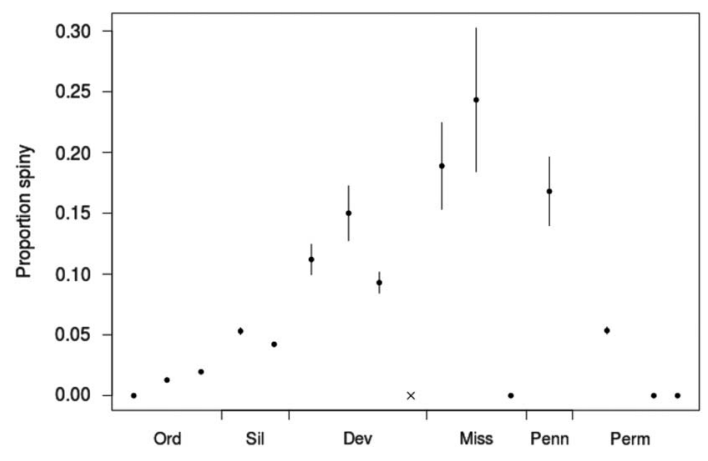

FIGURE 6. Proportion of crinoid genera originating in each interval bearing any spines, irrespective of spine location. Error bars indicate \pm 1 SE. The gray " $x$ " for the Famennian indicates that there are no genera in the data set originating in that interval. Dev, Devonian; Miss, Mississippian; Ord, Ordovician; Penn, Pennsylvanian; Perm, Permian; Sil, Silurian.

Late Devonian were heavily defended (e.g., Acanthocrinus, as discussed earlier), which suggests that at least some predation was present throughout the transition between the two faunas.

However, considering the anatomical locations and not just the overall incidence of spines, we can put forward a modification to the hypothesis: The change in predatory strategy between the Devonian and Carboniferous may have had a significant impact on which defensive traits were favored in Mississippian camerates. Calycal spines are more common in camerates before the Hangenberg extinction (increasing from $4 \%$ in the Silurian to $33 \%$ in the Famennian) than after it $(18 \%$ in the Tournaisian, falling to $12 \%$ by the Permian), while tegmenal spines are equally prevalent before and after it (from $4 \%$ in the Late Ordovician, increasing monotonically to $34 \%$ in the Viséan, then falling again; see also Fig. 4). Therefore, we suggest that spines on the dorsal cup may have been a defense against the shearing mode of predation that proved ineffective against crushing (the "legacy adaptation" of Ausich and Kammer [2013]), while crushing predators may still have been deterred by tegmenal spines from targeting either the crinoid or its parasites, as is the case with predators of modern snails (Whitenack and Herbert 2015). Alternatively, the difference may simply be a phylogenetic signal resulting from the elevated crinoid turnover rates during the Late
Devonian extinctions, although this would also require the anatomical location of spines to be a conserved trait over the $10 \mathrm{Myr}$ timescale. Further evaluation of this hypothesis would benefit from a biomechanical analysis of common Devonian and Mississippian crinoids' resistances to different mechanical stresses.

\section{Conclusions}

The disarticulated specimens measured here constitute evidence for a persistent 5-15\% frequency of proximal spine regeneration in crinoids of the most diverse higher taxa before and after the Devonian-Mississippian transition. This is comparable to the highest frequencies of arm regeneration in other Paleozoic crinoids and moderate-to-low frequencies in the Recent. However, specific comparisons to regeneration frequencies in other systems are difficult because of possible differences in the relationship between predation and regeneration and the problem of normalizing per part to per individual regeneration frequencies. Regeneration in cladid spines is less common during the Permian than during the Pennsylvanian, which may indicate either a drop in predation or a shift in predator ecological dominance. Further work will be required to determine whether the data here are representative of global changes in predator-prey relations, or if this is just a regional or even environmental pattern.

New data provide evidence for an association between platyceratid infestation and spinosity in the Devonian but not earlier. This is in line with other observations that predation intensity by durophagous predators was greatly intensified with the evolutionary radiation of gnathostome fishes in the Middle Devonian (Signor and Brett 1984; Brett 2003). These results are also consistent with a scenario in which Devonian predators preferentially targeted camerate calyces and tegmens, but Carboniferous predators instead targeted camerate tegmens and the anal sacs of cladids. Tegmen-dwelling parasitic platyceratid snails may also have been a common target of durophagous predators, as suggested by Brett et al. (2004), and consequently may have affected the evolution of deterrent spines on host crinoids.

Targeting of anal sacs, as postulated by Lane (1984), is also supported by the increasing 
occurrence of anal sac spines in post-Devonian cladids. The results here do not support the hypothesis of predatory release during the Mississippian camerate radiation as originally formulated by Sallan et al. (2011). However, the turnover they document among predatory fishes and the alteration in the dominant predatory strategy at the Devonian/Carboniferous boundary (Sallan 2013; Salamon et al. 2014) lead us to propose the alternative hypothesis that the extinction of shearing predators and their replacement by crushing predators, instead of producing an overall decrease in predation pressure, affected crinoid defensive adaptations by decreasing the efficacy of spines located on the dorsal cup.

\section{Acknowledgments}

The cladid spine injury rate data were collected by A. Reed as part of an undergraduate research internship with T.K.B. This work was partially funded by a grant from the National Science Foundation (DEB 1036260 to T.K.B.). Figure 2 by C. Abraczinskas, UMMP. The authors thank G. McIntosh for his input on platyceratid occurrence and spines in Devonian crinoids, including much unpublished material. We also thank B. Ausich, L. Sallan, J. Eckert, G. McIntosh, P. Signor, K. Purens, M. Veitch, J. Thomka, and S. Walker for helpful discussions. The authors thank Martin Aberhan and two anonymous reviewers for their comments on earlier versions of the article.

\section{Literature Cited}

Algeo, T. J., and P. H. Heckel. 2008. The Late Pennsylvanian Midcontinent Sea of North America: a review. Palaeogeography, Palaeoclimatology, Palaeoecology 268:205-221.

Amemiya, S., and T. Oji. 1992. Regeneration in sea lilies. Nature 357:546-547.

Arendt, Y. A. 2012. Traces of Augoichnus dituberculatus gen. et sp. nov. on Hypermorphocrinus magnospinosus from the Lower Permian of Cisuralia. Paleontological Journal 46:886-893.

Aronson, R. B. 1991. Predation, physical disturbance, and sublethal arm damage in ophiuroids: a Jurassic-Recent comparison. Marine Ecology Press Series 74:91-97.

Ausich, W. I., and T. W. Kammer. 2013. Mississippian crinoid biodiversity, biogeography and macroevolution. Palaeontology 56:727-740.

Bambach, R. K. 1999. Energetics in the global marine fauna: a connection between terrestrial diversification and change in the marine biosphere. Geobios 32:131-144.

—. 2002. Supporting predators: changes in the global ecosystem inferred from changes in predator diversity. Paleontological Society Papers 8:319-352.
Baumiller, T. K. 1990. Non-predatory drilling of Mississippian crinoids by platyceratid gastropods. Paleobiology 33:743-748.

— 1993. Survivorship analysis of Paleozoic Crinoidea: effect of filter morphology on evolutionary rates. Paleobiology 19: 304-321.

- 2002. Multi-snail infestation of Devonian crinoids and the nature of platyceratid-crinoid interactions. Acta Paleontologica Polonica 47:133-139.

—. 2003a. Evaluating the interaction between platyceratid gastropods and crinoids: a cost-benefit approach. Palaeogeography, Palaeoclimatology, Palaeoecology 201:199-209.

- 2003b. Experimental and biostratinomic disarticulation of crinoids: taphonomic implications. Pp. 243-248 in J. P. Feral and Bruno David, eds. Echinoderm Research 2001. Balkema, Rotterdam. - 2013a. Arm regeneration frequencies in Florometra serratissima (Crinoidea, Echinodermata): impact of depth of habitat on rates of arm loss. Cahiers de Biologie Marine 54:571-576.

_. 2013b. Ephemeral injuries, regeneration frequencies, and intensity of the injury-producing process. Marine Biology 160:3233-3239.

Baumiller, T. K., and F. J. Gahn. 2003. Predation on crinoids. In P. H. Kelley, M. Kowalewski, and T. A. Hansen, eds. Predator-prey interactions in the fossil record. Topics in Geobiology 20:263-278. Springer, New York.

- 2004. Testing predator-driven evolution with Paleozoic crinoid arm regeneration. Science 305:1453-1455.

- 2012. Reconstructing predation pressure on crinoids: estimating arm-loss rates from regenerating arms. Paleobiology 39:40-51.

Baumiller, T. K., R. Mooi, and C. G. Messing. 2008. Urchins in the meadow: paleobiological and evolutionary implications of cidaroid predation on crinoids. Paleobiology 34:22-34.

Baumiller, T. K., M. A. Salamon, P. Gorzelak, R. Mooi, C. G. Messing, and F. J. Gahn. 2010. Post-Paleozoic crinoid radiation in response to benthic predation preceded the Mesozoic Marine Revolution. Proceedings of the National Academy of Sciences USA 107:5893-5896.

Berner, R. A. 2006. GEOCARBSULF: a combined model for Phanerozoic atmospheric $\mathrm{O}_{2}$ and $\mathrm{CO}_{2}$. Geochimica et Cosmochimica Acta 70:5653-5664.

Bourgoin, A., and M. Guillou. 1994. Arm regeneration in two populations of Acrocnida brachiata (Montagu) (Echinodermata: Ophiuroidea) in Douarnenez Bay (Brittany, France): an ecological significance. Journal of Experimental Marine Biology and Ecology 184:123-139.

Bowsher, A. L. 1955. Origin and adaptation of platyceratid gastropods. In Mollusca, University of Kansas Paleontological Contributions 17.

Brett, C. E. 2003. Durophagous predation in Paleozoic marine benthic assemblages. In P. H. Kelley, M. Kowalewski, and T. A. Hansen, eds. Predator-prey interactions in the fossil record. Topics in Geobiology 20:401-432. Springer, New York.

Brett, C. E., and S. E. Walker. 2002. Predators and predation in Paleozoic marine environments. In M. Kowalewski and P. H. Kelley, eds. The fossil record of predation. Paleontological Society Papers 8:93-118.

Brett, C. E., F. J. Gahn, and T. K. Baumiller. 2004. Platyceratid gastropods as parasites, predators, and prey and their possible effects on echinoderm hosts: collateral damage and targeting. Geological Society of America Abstracts with Programs 36(5): 478.

Carnevali, M. D. C., E. Lucca, and F. Bonasoro. 1993. Mechanisms of arm regeneration in the feather star Antedon mediterranea: healing of wound and early stages of development. Journal of Experimental Zoology 267:299-317.

Clark, A. H. 1915. A monograph of the existing crinoids. Bulletin of the U.S. National Museum 82. U.S. Government Printing Office, Washington, D.C. 
Dahl, T. 2010. Devonian rise in atmospheric oxygen correlated to the radiations of terrestrial plants and large predatory fish. Proceedings of the National Academy of Sciences USA 107:17911-17915.

Donovan, S. K. 1992. Scanning EM study of the living cyrtocrinid Holopus rangii (Echinodermata, Crinoidea) and implications for its functional morphology. Journal of Paleontology 66: 665-675.

Feifarek, B. P. 1987. Spines and epibionts as antipredator defenses in the thorny oyster Spondylus americanus Hermann. Journal of Experimental Marine Biology and Ecology 105:39-56.

Fishelson, L. 1974. Ecology of the Northern Red Sea crinoids and their epi- and endozoic fauna. Marine Biology 26:183-192.

Gahn, F. J., and T. K. Baumiller. 2003. Infestation of Middle Devonian (Givetian) camerate crinoids by platyceratid gastropods and its implications for the nature of their biotic interaction. Lethaia 36:71-82.

- 2005. Arm regeneration in Mississippian crinoids: evidence of intense predation pressure in the Paleozoic? Paleobiology 31:151-164.

- 2006. Using platyceratid gastropod behaviour to test functional morphology. Historical Biology 18:397-404.

- 2010. Evolutionary history of regeneration in crinoids (Echinodermata). Integrative and Comparative Biology 50: $514 \mathrm{a}-514 \mathrm{~m}$.

Gahn, F. J., A. Fabian, and T. K. Baumiller. 2003. Additional evidence for the drilling behavior of Paleozoic gastropods. Acta Palaeontologica Polonica 48:156.

Goldring, W. 1923. Devonian crinoids of the State of New York. New York State Memoirs 16.

Hess, H. 2014. The crinoid Eugeniacrinites cariophilites from the Late Jurassic of Southern Germany: babies, cripples and enigmatic wing plates. Swiss Journal of Palaeontology 133:121-140.

Janevski, G. A., and T. K. Baumiller. 2010. Could a stalked crinoid swim? A biomechanical model and characteristics of swimming crinoids. Palaios 25:588-596.

Johnsen, S. A. L., M. Ahmed, and L. R. Leighton. 2013. The effect of spines of a Devonian productide brachiopod on durophagous predation. Palaeogeography, Palaeoclimatology, Palaeoecology 375:30-37.

Kammer, T. W., and W. I. Ausich. 2007. Soft-tissue preservation of the hind gut in a new genus of cladid crinoid from the Mississippian (Visean, Asbian) at St Andrews, Scotland. Palaeontology 50:951-959.

Katz, S. G., and J. Sprinkle. 1976. Fossilized eggs in a Pennsylvanian blastoid. Science 192:1137-1139.

Kesling, R. V. 1965. Nature and occurrence of Gennaeocrinus goldringae Ehlers. Contributions from the University of Michigan Museum of Paleontology 29:265-280.

Kluessendorf, J. 1983. Observations on the commensalism of Silurian platyceratid gastropods and stalked echinoderms. Transactions of the Wisconsin Academy of Sciences, Arts, and Letters 71:48-55.

Kowalewski, M., A. P. Hoffmeister, T. K. Baumiller, and R. K. Bambach. 2005. Secondary evolutionary escalation between brachiopods and enemies of other prey. Science 308:1774-1777.

Lach, R., K. Brom, and K. Leśko. 2015. Bite marks and overgrowths on crinoids from the Štramberk-type limestones in Poland. Neues Jahrbuch für Geologie und Paläontologie - Abhandlungen 276:151-154.

Lane, N. G. 1984. Predation and survival among inadunate crinoids. Paleobiology 10:453-458.

Lawrence, J. M. 2009. Arm loss and regeneration in stellate echinoderms: an organismal view. Pp. 53-66 in Craig Johnson, ed. Echinoderms in a changing world: Proceedings of the 13th International Echinoderm Conference. Hobart, Tasmania.

Lawrence, J. M., and J. Vasquez. 1996. The effect of sublethal predation on the biology of echinoderms. Oceanologica Acta 19:431-440.
Leighton, L. R. 2001. New example of Devonian predatory boreholes and the influence of brachiopod spines on predator success. Palaeogeography, Palaeoclimatology, Palaeoecology 165:53-69.

Lowe, E. F. 1979. Relations between biochemical and caloric composition and reproductive cycle in Asterias vulgaris (Echinodermata) from the Gulf of Maine. Dissertation Abstracts International B 40(1):30-31.

Lucas, J. S., R. Hart, M. Howden, and R. S. Salathe. 1979. Saponins in eggs and larvae of Acanthaster planci (L.) (Asteroidea) as chemical defenses against planktivorous fish. Journal of Experimental Marine Biology F 40:155-165.

Meyer, D. L. 1985. Evolutionary implications of predation on recent comatulid crinoids from the Great Barrier Reef. Paleobiology 11:154-164.

Meyer, D. L., and William I. Ausich. 1983. Biotic interactions among recent and among fossil crinoids. In Michael J. S., Tevesz, and Peter L. McCall, eds. Biotic interactions in recent and fossil benthic communities. Topics in Geobiology 3:377-427. Plenum, New York.

Meyer, D. L., and D. B. Macurda. 1977. Adaptive radiation of the comatulid crinoids. Paleobiology 3:74-82.

Miller, D. J., and M. Labarbera. 1995. Effects of foliaceous varices on the mechanical properties of Chicoreus dilectus (Gastropoda: Muricidae). Journal of Zoology 236:151-160.

Mladenov, P. V. 1983. Rate of arm regeneration and potential causes of arm loss in the feather star Florometra serratissima (Echinodermata: Crinoidea). Canadian Journal of Zoology 61:2873-2879.

Moore, R., H. W. Rasmussen, N. G. Lane, G. Ubaghs, H. L. Strimple, R. E. Peck, J. Sprinkle, R. O. Fay, and H. Sieverts-Doreck. 1978. Crinoidea 2. Pp. T403-T812 in G. Ubaghs et al. Echinodermata 2, Crinoidea. Part T of R. C. Moore, ed., Treatise on invertebrate paleontology. Geological Society of America, Boulder, and University of Kansas, Lawrence.

Moore, R. C., and R. M. Jeffords. 1968. Classification and nomenclature of fossil crinoids based on studies of dissociated parts of their columns. University of Kansas Paleontological Contributions 46, Echinodermata 9.

Morris, R. W., and S. H. Felton. 1993. Symbiotic association of crinoids, platyceratid gastropods, and cornulites in the Upper Ordovician (Cincinnatian) of the Cincinnati, Ohio region. Palaios 8:465-476.

Nakano, H., S. Amemiya, T. Hibino, Y. Hara, and T. Oji. 2004. Development of the sea lily Metacrinus rotundus: comparisons with feather stars. Pp. 41-44 in T. Heinzeller and J. Nebelsick, eds. Echinoderms. Taylor \& Francis, Munich.

Nichols, D. 1996. Evidence for a sacrificial response to predation in the reproductive strategy of the comatulid crinoid Antedon bifida from the English Channel. Oceanologica Acta 19:237-240.

Nichols, D., G. M. Bishop, and A. A. T. Sime. 1982. An annual reproductive and nutritional cycle in the European sea urchin Echinus esculentus in the Plymouth area. Pp. 451-457 in J. M. Lawrence, ed. International Echinoderm Conference, Tampa Bay. Balkema, Rotterdam.

Obuchi, M., Y. Fujita, Y. Nakano, T. Uehara, and T. Motokawa. 2010. Reproductive biology and early life history of the hermaphroditic feather star Dorometra sesokonis (Echinodermata: Crinoidea). Marine Biology 157:1191-1201.

Oji, T. 1996. Is predation intensity reduced with increasing depth? Evidence from the West Atlantic stalked crinoid Endoxocrinus parrae (Gervais) and implications for the Mesozoic Marine Revolution. Paleobiology 22:339-351.

—. 2001. Fossil record of echinoderm regeneration with special regard to crinoids. Microscopy Research and Technique 55: 397-402.

Oji, T., and T. Okamoto. 1994. Arm autotomy and arm branching pattern as anti-predatory adaptations in stalked and stalkless crinoids. Paleobiology 20:27-39. 
Paine, R. T. 1966. Food web complexity and species diversity. American Naturalist 100:65-75.

Rollins, H. B., and D. K. Brezinski. 1988. Reinterpretation of crinoidplatyceratid interaction. Lethaia 21:207-217.

Roux, M. 1976. Aspect de la variabilité et de la croissance au sein d'une population de la pentacrine actuelle: Annacrinus wyvillethomsoni Jeffreys (Crinoidea). Thallasia Jugoslavica 12:307-320.

Salamon, M. A., P. Gorzelak, R. Niedźwiedzki, D. Trzęsiok, and T. K. Baumiller. 2014. Trends in shell fragmentation as evidence of mid-Paleozoic changes in marine predation. Paleobiology 40:1-10.

Sallan, L. C. 2013. The end-Devonian Hangenberg event: causes and consequences of a major bottleneck in vertebrate evolution. Geological Society of America Abstracts with Programs 45:319.

Sallan, L. C., and M. I. Coates. 2010. End-Devonian extinction and a bottleneck in the early evolution of modern jawed vertebrates. Proceedings of the National Academy of Sciences USA 107:10131-10135.

Sallan, L. C., T. W. Kammer, W. I. Ausich, and L. A. Cook. 2011. Persistent predator-prey dynamics revealed by mass extinction. Proceedings of the National Academy of Sciences USA 108: 8335-8338.

Schneider, C. L. 2001. Heaps of echinoids in a Pennsylvanian echinoderm Lagerstätte: implications for fossilized behavior. Paleobios 21:113.

Schneider, J. A. 1988. Frequency of arm regeneration of comatulid crinoids in relation to life habit. Pp. 531-538 in R. D. Burke, P. V. Mladenov, P. Lambert, and R. L. Parsley, eds. Echinoderm biology: proceedings of the sixth international echinoderm conference. Balkema, Rotterdam.

Signor, P. W., and C. E. Brett. 1984. The Mid-Paleozoic precursor to the Mesozoic Marine Revolution. Paleobiology 10:229-245.

Springer, F. 1920. The Crinoidea Flexibilia (with an atlas of A., B., C., and 76 plates). Publications of the Smithsonian Institute 2501. Washington, D.C.: Smithsonian Institution.

Stevenson, A., F. J. Gahn, T. K. Baumiller, and G. D. Sevastopulo. 2017. Predation on feather stars by regular echinoids as evidenced by laboratory and field observations and its paleobiological implications. Paleobiology 43:274-285.
Syverson, V. J., and T. K. Baumiller. 2014. Temporal trends of predation resistance in Paleozoic crinoid arm branching morphologies. Paleobiology 40:417-427.

Syverson, V. J., C. G. Messing, K. Stanley, and T. K. Baumiller. 2014. First insights into growth and population dynamics in the extant cyrtocrinid Holopus mikihe (Crinoidea) near Roatán, Honduras. Bulletin of Marine Science 91:47-61.

Terborgh, J. W. 2015. Toward a trophic theory of species diversity. Proceedings of the National Academy of Sciences USA 112:11415-11422.

Thompson, J. R., and W. I. Ausich. 2015. Testing for escalation in Lower Mississippian camerate crinoids. Paleobiology 41: 89-107.

Veitch, M. A., C. G. Messing, and T. K. Baumiller. 2015. Contractile connective tissue (CCT) in the stalk of the bourgueticrinid crinoid Democrinus: functional, ecological, and evolutionary implications. Geological Society of America Abstracts with Programs 47:855.

- 2016. Escape to the deep? Assessing predation intensity on bathyal stalked crinoids using injury frequencies and rates of arm regeneration. Geological Society of America Abstracts with Programs 48(7). doi: 10.1130/abs/2016AM-286379.

Wachsmuth, C., and F. Springer. 1897. The North American Crinoidea Camerata. Memoirs of the Museum of Comparative Zoology at Harvard College 20-21. Harvard Museum of Comparative Zoology, Cambridge.

Waters, J. A., and C. G. Maples. 1991. Mississippian pelmatozoan community reorganization: a predation-mediated faunal change. Paleobiology 17:400-410.

Webster, G. D. 2013. Bibliography and index of Paleozoic crinoids, coronates, and hemistreptocrinoids, 1758-2012. Geological Society of America Special Paper 363.

Whitenack, L. B., and G. S. Herbert. 2015. Did shell-crushing crabs trigger an escalatory arms race in the aftermath of a Late Neogene regional mass extinction event? An experimental test. Palaeogeography, Palaeoclimatology, Palaeoecology 417:57-65.

Wright, D. F., W. I. Ausich, S. R. Cole, M. E. Peter, and E. C. Rhenberg. 2017. Phylogenetic taxonomy and classification of the Crinoidea (Echinodermata). Journal of Paleontology 91:829-846. 